\title{
Opisthobranch molluscs from the subtidal trawling grounds off Blanes (Girona, north-east Spain)
}

\author{
Anna Domènech*, Conxita Avila ${ }^{\dagger}$ and Manuel Ballesteros* ${ }^{\ddagger}$ \\ *Departamento de Biologia Animal, Universitat de Barcelona, Avenida Diagonal 645, 08028 Barcelona, Spain. \\ ${ }^{\dagger}$ Centre d'Estudis Avançats de Blanes (Consejo Superior de Investigaciones Científicas), c/ Accés a la Cala Sant Francesc, 14, 17300 \\ Blanes, Girona, Spain. ${ }^{\ddagger}$ Corresponding author, e-mail: mballesteros@ub.edu
}

\begin{abstract}
Studies on the opisthobranch molluscs inhabiting the continental platform in areas not accessible by SCUBA diving are rare in the subtidal bottoms of the Iberian Peninsula. Data obtained from trawls are not adequate for quantitative analysis, due to the indirect method used and the high number of variables which affect the capture of the samples. However, with the aim of obtaining qualitative information on the opisthobranch molluscs inhabiting the subtidal trawling grounds off Blanes, we took more than 500 samples over a two-year period, on the non-commercial fraction of the trawling fisheries, finding opisthobranchs in 306 samples. We analysed samples from 16 trawling sites, at depths between 50 and $300 \mathrm{~m}$, by using ten fishing boats of the 'Confraria de Pescadors del Port de Blanes'. We obtained 4.295 specimens of opisthobranchs belonging to 29 species. From these, 4 are Cephalaspidea s.s., 1 Anaspidea, 1 Umbraculacea, 3 Pleurobranchacea and 20 Nudibranchia (3 Arminina, 3 Dendronotina and 14 Doridina). The most abundant species were Gastropteron rubrum and Scaphander lignarius, both cephalaspideans present during all seasons, and the dendronotacean Tethys fimbria. For Scaphander lignarius it was possible to distinguish three size-groups, from which the smallest one was usually found in summer. Other interesting species found were, among others, Armina tigrina, Baptodoris cinnabarina, Thordisa filix and Kaloplocamus ramosus. The richest trawling grounds in species numbers and abundances were La Planassa and Els Capets. The total number of opisthobranch species reported for the trawling grounds off Blanes is now 48.
\end{abstract}

\section{INTRODUCTION}

Studies on the opisthobranch molluscs inhabiting the continental platform in areas not accessible by SCUBA diving are rare in the Iberian Peninsula subtidal as well as in other marine areas of the world. In a previous study (Ros, 1975), 35 species were reported from the trawling grounds off Blanes obtained from commercial fishery trawling for cephalopods and benthic fish. Ballesteros (1986) mentioned other species in the same subtidal area, some of them never recorded previously for Catalan and Iberian waters. The oceanographic cruise Fauna I carried out in 1989 on circalittoral (understandig circalittoral as those depths where the light intensity is reduced to a level where it will no longer support substantial algal growth) areas in the south Iberian Peninsula (with a net of $10 \mathrm{~mm}$ mesh-size) reported 35 opisthobranch species (Templado et al., 1993). The oceanographic cruise Fauna III carried out in 1994 in bathyal areas surrounding the Balearic Islands and the Columbretes Islands (also with a net of $10 \mathrm{~mm}$ mesh-size) reported 70 species (Ballesteros \& Templado, unpublished results). Available data from the trawling grounds off Blanes refer only to the presence and/or characteristics of some particular opisthobranch species (Ballesteros, 1981, 1983; Ortea et al., 1996; Ballesteros et al., 1999; Ballesteros \& Valdés, 1999).

A usual problem for this kind of study is that data obtained from trawls are not adequate for quantitative analysis, due to the indirect method used and the high number of variables which affect the capture of the samples (mesh size, precise size of sampled area, manual ability in the sorting of samples out from the commercial fraction, duration of trawling, etc.). Furthermore, the results should be considered with caution, since the use of trawls may bias the collected samples and they may only represent a part of the real population (big sized species or very abundant species). Being aware of the complexity of this kind of study, and with the aim of obtaining qualitative information on the opisthobranch molluscs inhabiting the subtidal trawling grounds off Blanes, we decided to study the samples from the non-commercial fraction of the trawling fisheries. We took more than 500 samples over a two-year period finding opisthobranchs in 306 samples. This study reports the results of the analysis of these samples and provides information on faunistic characteristics, species composition and abundance of opisthobranch molluscs in the subtidal trawling grounds off Blanes (Girona, north-east Spain).

\section{MATERIALS AND METHODS}

More than 500 samples were taken during the years 1999 and 2000 from the non-commercial fraction of the trawling fishery on board ten fishing boats of the 'Confraria de Pescadors del Port de Blanes'. Opisthobranch molluscs were found in 306 samples. The trawling method used was the classical Catalan 'bou' which is used for capturing benthic fish and cephalopods, and epibenthic crustaceans. A sample was considered to be the material sorted for a 


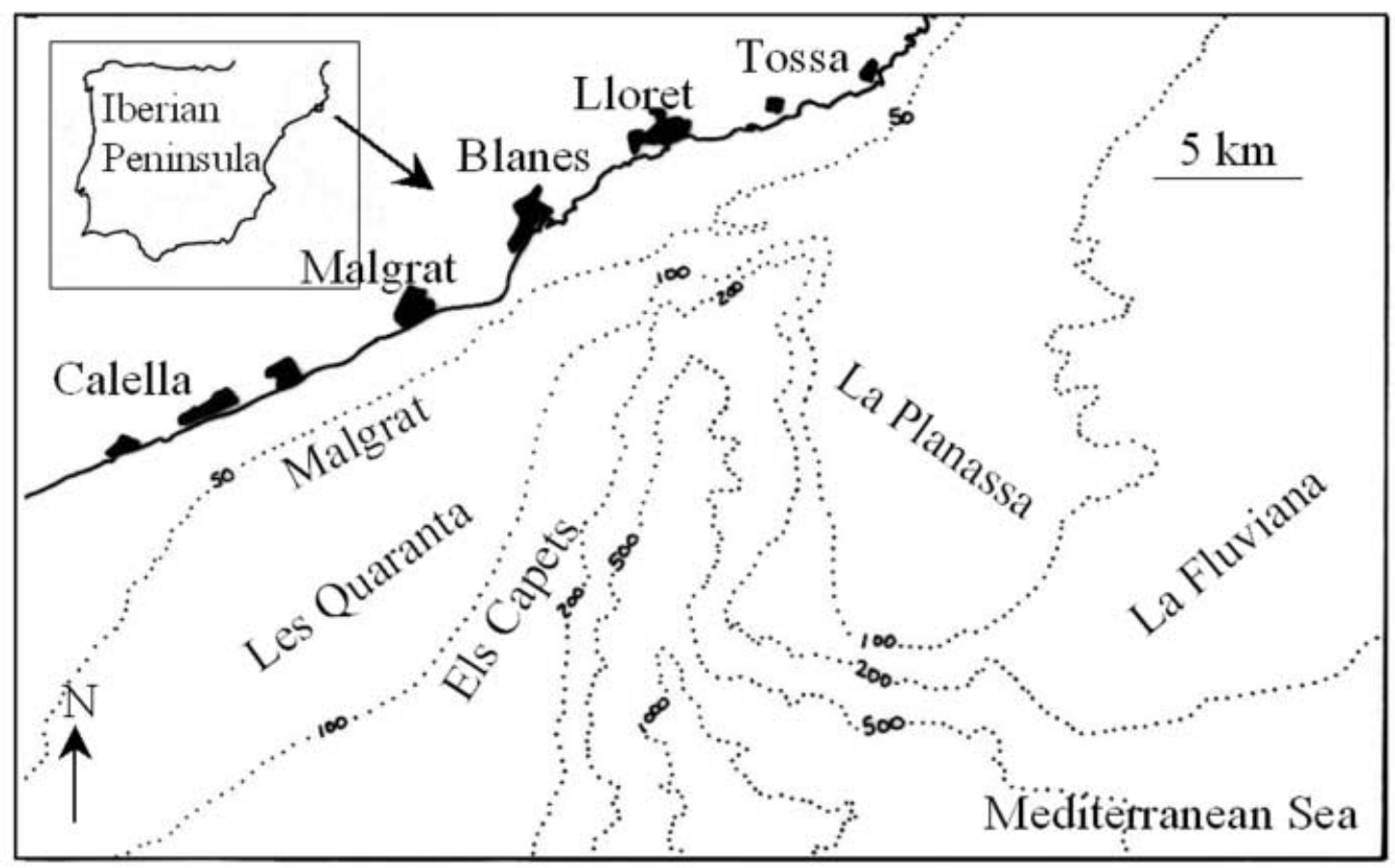

Figure 1. Geographical situation of the trawling grounds sampled, located in front of the Catalan coast between the cities of Calella de Mar (Barcelona) and Tossa de Mar (Girona). Black marks on land represent cities. Dashed lines refer to depths ranging from 50 to $1000 \mathrm{~m}$.

specific trawling ground for a specific fishing boat and day. Whenever two different boats were fishing in the same ground the same day we considered it to be two different samples. Also, if a specific boat was fishing in two different grounds during the same day, we considered it to be two different samples. Usually, every fishing boat provided 2-3 samples/day and each trawling lasted about $2 \mathrm{~h}$. We analysed samples from 16 trawling grounds located in the subtidal area from Calella de Mar (Barcelona) to Tossa de Mar (Girona) at depths ranging between 50 and $300 \mathrm{~m}$ (Figure 1). These different trawling grounds are separated by the Blanes Canyon which has a depth of $>1000 \mathrm{~m}$. The most visited trawling grounds were Les Quaranta, La Planassa, Els Capets, Terra Malgrat and La Fluviana, with 16 to 84 samples each (Table 1). These five ground areas possess different bathymetric and biological characteristics, as well as different kinds of substrate (Table 1). Other trawling areas sampled were: El Cap (24 n.m.; 40-86 m depth), Davant Tossa-Terra Les Bruixes (113-128 m depth), Davant Tossa-Terra Amèrica (5 n.m.; 99-108 m depth), Les Garotes (1 n.m.; 50-60 m depth), Penjant de La Planassa (6-7 n.m.; 97-180 m depth), La Miquela (13 n.m.; 60-108 m), Mar de Calella (54-72 m depth), Dintre es fons (1.5 n.m.; 52-60 m depth), La Rocassa (3.5-4 n.m.; 180-540 m depth), Can Farrer (6 n.m.; 540 m depth), Amèrica (8 n.m.; 112 m depth), l'Aguda (6 n.m.; 90 m depth), Terra la Creu (7-8 n.m.; 252-270 m depth) and Fora la Planassa (10-11 n.m.; 142-144 m depth). The areas surrounding the Blanes harbour were previously studied by Rubió (1971) and Ros (1975).

Some previous studies on sponges, ascidians and cnidarians of the Catalan subtidal provided information on the

Table 1. Main trawling areas studied, with some bathymetrical and biological characteristics, and number of samples studied.

\begin{tabular}{|c|c|c|c|c|c|}
\hline Trawling area & $\begin{array}{l}\text { Distance to } \\
\text { the coast (n.m.) }\end{array}$ & Depth (m) & Bottom type & Main associated fauna & $\begin{array}{l}\text { No. of } \\
\text { samples }\end{array}$ \\
\hline Les Quaranta & $3-5$ & $70-96$ & Sand and stones & $\begin{array}{l}\text { Echinoderms, pennatulaceans, ascidians, } \\
\text { cephalopods }\end{array}$ & 24 \\
\hline La Planassa & $4-12$ & $76-144$ & Sand & $\begin{array}{l}\text { Sponges, echinoderms, pennatulaceans, } \\
\text { cephalopdos, fish }\end{array}$ & 84 \\
\hline Els Capets & $2-10$ & $90-156$ & Mud & Crinoids, cephalopods, hermit crabs & 73 \\
\hline Malgrat* & $1-2$ & $50-60$ & Mud & $\begin{array}{l}\text { Sponges, alcyonaceans, pennatulaceans, } \\
\text { cephalopods }\end{array}$ & 29 \\
\hline La Fluviana & $9-17$ & $110-150$ & Mud & Crinoids, cephalopods & 16 \\
\hline
\end{tabular}

n.m., nautical miles; *, near three submarine seawage outfalls. 
Table 2. Comparative data of total abundances and frequencies of the opisthobranch species collected in the trawling areas off Blanes during this study (1999-2000) and those mentioned in Ros (1975). Frequencies have been calculated from the total samples in which opisthobranch were found (306).

\begin{tabular}{|c|c|c|c|}
\hline & Abundances & $\begin{array}{c}\text { Frequencies } \\
(\%)\end{array}$ & $\begin{array}{c}\text { Ros } \\
(1975)\end{array}$ \\
\hline Gastropteron rubrum & 1599 & 44.44 & $>100$ \\
\hline Tethys fimbria & $789 *$ & $43.13^{*}$ & 11 \\
\hline Scaphander lignarius & 620 & 26.14 & 57 \\
\hline Marionia blainvillea & 430 & 34.64 & 1 \\
\hline Pleurobranchaea meckeli & 240 & 26.79 & 5 \\
\hline Doriopsilla areolata & 169 & 14.37 & 0 \\
\hline Dendrodoris limbata & 65 & 9.47 & 26 \\
\hline Pleurobranchus membranaceus & 51 & 26.79 & 6 \\
\hline Kaloplocamus ramosus & 36 & 6.86 & 1 \\
\hline Armina neapolitana & 36 & 4.90 & 0 \\
\hline Armina maculata & 35 & 8.82 & 0 \\
\hline Umbraculum mediterraneum & 30 & 6.86 & $\mathrm{i}$ \\
\hline Baptodoris cinnabarina & 26 & 5.55 & 0 \\
\hline Doriopsilla pelseneeri & 23 & 3.26 & 0 \\
\hline Philine aperta & 23 & 4.24 & 6 \\
\hline Aplysia depilans & 22 & 2.94 & $\mathrm{i}$ \\
\hline Doris pseudoargus & 19 & 3.26 & $\mathrm{i}$ \\
\hline Armina tigrina & 18 & 5.88 & 0 \\
\hline Pleurobranchus testudinarius & 17 & 1.30 & 3 \\
\hline Thordisa filix & 12 & 2.28 & 0 \\
\hline Lomanotus marmoratus & 11 & 1.30 & 0 \\
\hline Doris sticta & 6 & 0.98 & 0 \\
\hline Aglaja tricolorata & 6 & 2.28 & 0 \\
\hline Forunna cf. tomentosa & 4 & 1.30 & 3 \\
\hline Okenia elegans & 2 & 0.65 & 0 \\
\hline Geitodoris cf. planata & 2 & 0.65 & 0 \\
\hline Hypselodoris fontandraui & 1 & 0.32 & 0 \\
\hline Chromodoris purpurea & 1 & 0.32 & 0 \\
\hline Dorid sp. $* *$ & 2 & 0.65 & 0 \\
\hline Cylichna cylindracea & 0 & 0 & $>100$ \\
\hline Cymbulia peroni & 0 & 0 & $>100$ \\
\hline Discodoris stellifera & 0 & 0 & 6 \\
\hline Berthella ocellata & 0 & 0 & 4 \\
\hline Scaphander punctostriatus & 0 & 0 & 3 \\
\hline Faponacteon pusillus & 0 & 0 & 2 \\
\hline Philine aperta & 0 & 0 & 2 \\
\hline Tritonia plebeia & 0 & 0 & 1 \\
\hline Tritonia sp. & 0 & 0 & 1 \\
\hline Notarchus punctatus & 0 & 0 & 1 \\
\hline Doris verrucosa & 0 & 0 & 1 \\
\hline Doris sp. & 0 & 0 & 1 \\
\hline Doriopsilla pusilla & 0 & 0 & 1 \\
\hline Phyllidia sp. & 0 & 0 & 1 \\
\hline Facelina drumondi & 0 & 0 & $\mathrm{i}$ \\
\hline Peltodoris atromaculata & 0 & 0 & $\mathrm{i}$ \\
\hline Hypselodoris picta & 0 & 0 & $\mathrm{i}$ \\
\hline Hypselodoris villa franca & 0 & 0 & $\mathrm{i}$ \\
\hline Tritonia hombergi & 0 & 0 & $\mathrm{i}$ \\
\hline Berthella aurantiaca & 0 & 0 & $\mathrm{i}$ \\
\hline
\end{tabular}

i, not specified; *, in our study the specimens of Tethys fimbria were more abundant than indicated here, but not all the specimens were collected; **, the identification of these specimens was not possible because of their bad shape.

main species inhabiting some of these areas (Rubió, 1971; Gili et al., 1987a,b; Gili \& Pagès, 1987; Turón, 1988). With these literature data and also with our own data, we can provide a short description of the five main trawling areas.
The main species of invertebrates found in Les Quaranta are the echinoderms Astropecten sp. and Anseropoda placenta, the pennatulaceans Pennatula rubra and Pteroides spinosum, the ascidians Ascidia mentula, Ascidiella aspersa, Phallusia fumigata and Botryllus schlosseri, the cephalopods Loligo vulgaris, Eledone cirrhosa, Eledone moschata, Octopus vulgaris and Sepia officinalis, the fish Engraulis encrasicholus, Trachinus draco, Pagellus acarne, Boops boops, Merluccius merluccius, Mullus spp., Sardina pilchardus, Serranus cabrilla, and hermit crabs such as Pagurus arrosor.

In La Planassa, the most abundant invertebrates are the sponges Agelas oroides, Tethya aurantium and Axinella sp., the echinoderms Astropecten sp., Anseropoda placenta, Spatangus purpureus, Cidaris cidaris, Antedon mediterranea, Stichopus regalis and Cucumaria sp., the pennatulaceans Pennatula rubra and Pteroides spinosum, the cephalopods Todarodes sagittatus, Sepia elegans, Sepiola rondeleti, Octopus vulgaris and Eledone chirrosa, the fish Trachinus draco, Boops boops, Cepola rubescens, Merluccius merluccius, Trigla lucerna, Lophius piscatorius, Mullus spp., Sardina pilchardus, Trachurus trachurus, Scomber scombrus, and Spicara smaris, and the molluscs Lamellaria sp.

In the area of Els Capets, the main fauna comprises the crinoid Antedon mediterranea, the hermit crabs Pagurus arrosor, the cephalopods Sepia elegans, Eledone cirrhosa and Octopus vulgaris, and the fish Trachinus draco, Gobius niger, Trisopterus minutus, Merluccius merluccius, Trigla lucerna, Micromesistius poutassou, Lophius piscatorius, Uranoscopus scaber, Mullus barbatus and Chelidonichthys cuculus, and the molluscs Lamellaria sp.

In the trawling area of Malgrat, the sponges Suberites domuncula, the cnidarians Alcyonium sp., Pennatula rubra, Veretillum sp., the cephalopods Loligo vulgaris and Sepia officinalis, the fish Trachinus draco, and the sipunculid Sipunculus nudus are the main species found.

In La Fluviana the crinoids are the most abundant species (Antedon mediterranea), as well as the cephalopods Loligo vulgaris and the fish Trisopterus minutus, Merluccius merluccius, Lophius piscatorius and Mullus barbatus.

The opisthobranchs obtained from each sample were sorted from the non-commercial fraction of the capture by hand (occasionally the fishermen helped sorting the sample when needed). The opisthobranchs collected were kept in fresh seawater until arriving at Blanes harbour. The trawling produced some deterioration in some specimens and this made it difficult for their further identification. However, only in one case was it impossible to identify the genus (Dorid sp.). In the laboratory the material was kept in fresh seawater, separated by taxonomic groups and studied under the microscope for identification. After that, they were photographed and then they were either frozen for further studies on their chemical ecology or they were fixed in $70 \%$ ethanol for anatomical studies. When necessary, the study of the radula was carried out under scanning electron microscopy. The computer software program PRIMER was used for statistical comparisons between the faunistic composition of opisthobranchs from the main five trawling grounds. For taxonomy, we follow the last phylogenetic analysis based on morphological studies and molecular data proposed by Cervera et al. (2004) in their checklist of the opisthobranchs from Spain and Portugal. 

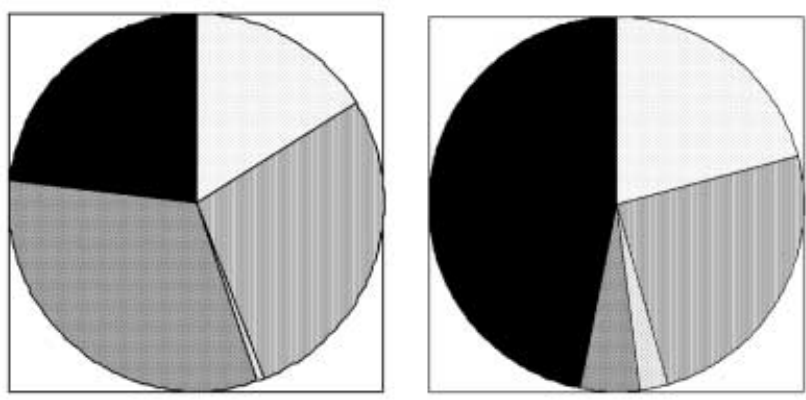

La Planassa

\section{Les Quaranta}

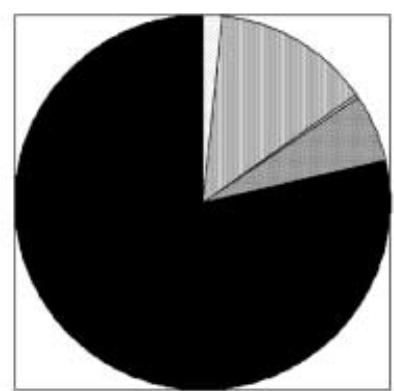

Els Capets
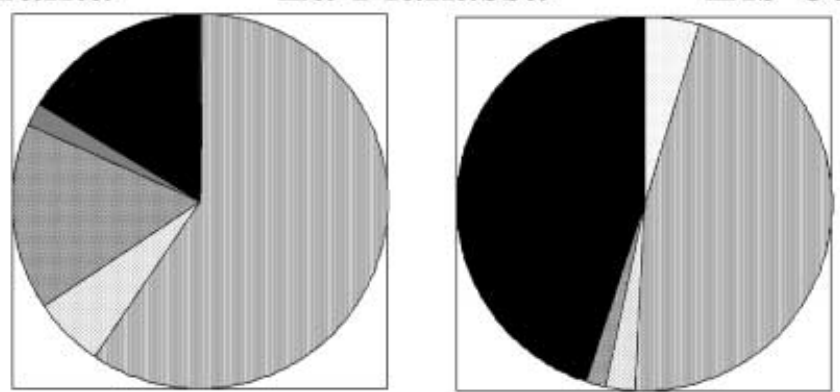

\section{La Fluviana}

Doridina

$\square$ Pleurobranchacea $\square$ Dendronotina

Anaspidea

\section{Arminina}

- Cephalaspidea

Figure 2. Percentage of opisthobranchs collected in the five main trawling grounds studied during 1999 and 2000 off Blanes.

\section{RESULTS}

From more than 500 samples, opisthobranchs were found in 306 of them, approximately $62 \%$ of the samples. A total of 4295 specimens was collected, belonging to 29 different species (Table 2). From these species, 4 were Cephalaspidea s.s., 1 Anaspidea, 1 Umbraculacea, 3 Pleurobranchacea and 20 Nudibranchia (3 Arminina, 3 Dendronotina and 14 Doridina). The most abundant species were, in this order, the cephalaspidean Gastropteron rubrum with 1599 specimens, the dendronotacean Tethys fimbria with 789 specimens, the cephalaspidean Scaphander lignarius with 620 specimens, and the dendronotacean Marionia blainvillea with 430 specimens. All together the abundances of these four species represented $80 \%$ of the total opisthobranchs collected (Table 2). For the dendronotacean Tethys fimbria it should be stated though, that more animals were present, but occasionally they were not collected by the fishermen.

The percentages of abundances of the different taxonomic groups in the five main trawling grounds were very different (Figure 2). Cephalaspidea s.s. are the most abundant group in La Planassa and Els Capets, while in La Fluviana, and especially in Malgrat, the Dendronotina are more abundant. In Les Quaranta the Notaspidea are predominant. By taxonomic groups, Cephalaspidea s.s. and Dendronotina are the most abundant (Table 3). From the five main trawling grounds (with 16-84 samples, i.e. Les Quaranta, La Planassa, Els Capets, Terra Malgrat and La Fluviana), the richest in species numbers and abundances were La Planassa and Els Capets (Figure 3), where more than 1000 opisthobranchs were collected (1108
Table 3. Total species richness and abundances collected during 1999-2000 in the trawling areas by taxonomic groups.

\begin{tabular}{lcc}
\hline & Species richness & Abundances \\
\hline Cephalaspidea s.s. & 4 & 2248 \\
Umbraculacea & 1 & 30 \\
Pleurobranchacea & 3 & 308 \\
Anaspidea & 1 & 22 \\
Nudibranchia Arminina & 3 & 89 \\
Nudibranchia Dendronotina & 3 & 1230 \\
Nudibranchia Doridina & 13 & 368 \\
Total & 28 & 4295 \\
\hline
\end{tabular}

and 1164, respectively). Les Quaranta is the trawling ground with lower abundances, with about 222 specimens. For species richness, in four of the five sites (Les Quaranta, La Planassa, Els Capets and La Fluviana) more than 15 species were found, while in Terra Malgrat only 10 species were collected (Figure 3). However, looking at the same data taking into account the sampling effort (i.e. number of samples taken in each site) the trawling grounds with higher specimens/sample values are La Fluviana and Malgrat with more than 15 individuals/sample, and the richest sites in species/sample are La Fluviana and Les Quaranta (Figure 3).

Gastropteron rubrum and Scaphander lignarius appeared in the samples during the whole year. For Scaphander lignarius it was possible to distinguish three size-groups, from which the smallest one was usually found in summer. Other interesting species found were, among others, Armina 
Total abundance

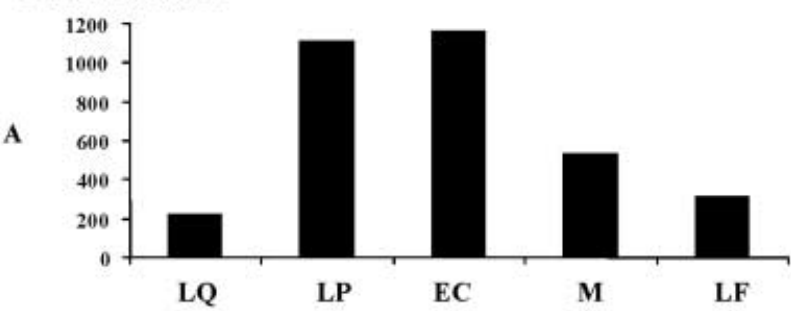

Total abundances/sample

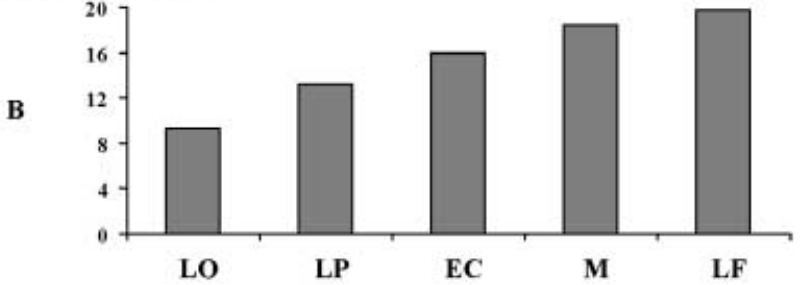

Total species richness

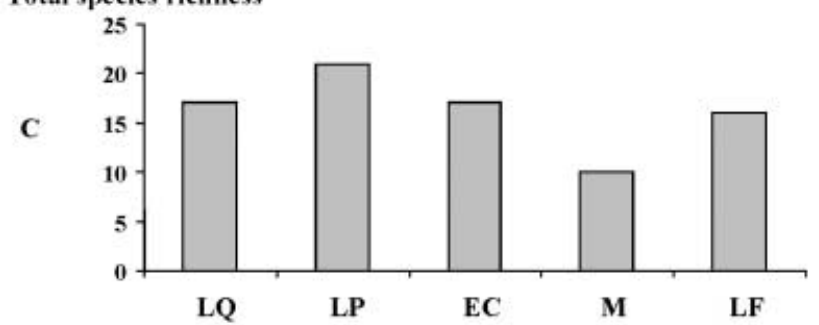

Total species/sample

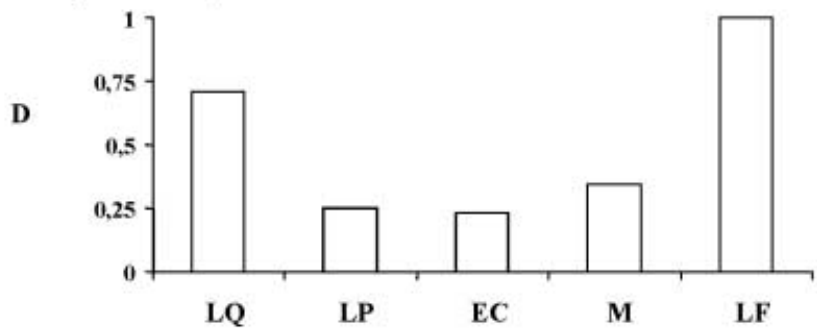

Figure 3. Abundances and species richness of opisthobranch molluscs in the five main trawling grounds studied (1999-2000) off Blanes (LQ, Les Quaranta; LP, La Planassa; EC, Els Capets; M, Malgrat; LF, La Fluviana). (A) Total abundances; (B) total abundances/sample; $(\mathrm{C})$ total species richness; and (D) total species/sample.

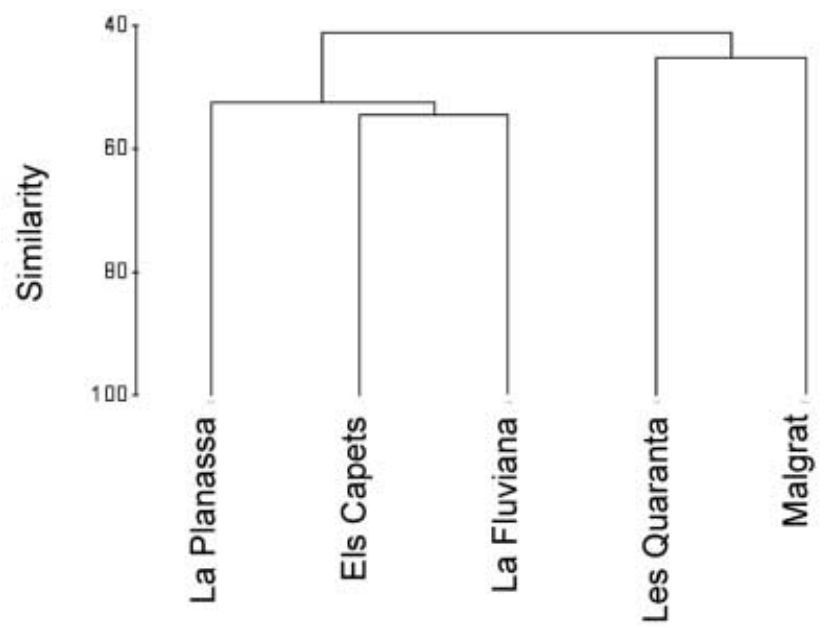

Figure 4. Dendrogram of species richness similarity obtained with the computer software program PRIMER from the different trawling grounds off Blanes sampled during this study (1999-2000).
Table 4. Opisthobranchs from the trawling areas off Blanes compiled after this study (1999-2000) and that of Ros (1975) and Ballesteros (1986).

$\begin{array}{lc}\text { Architectibranchia } & \text { Nudibranchia Arminina } \\ \text { Japonacteon pusillus } & \text { Armina neapolitana } \\ \text { Cephalaspidea s.s. } & \text { Armina maculata } \\ \text { Gastropteron rubrum } & \text { Armina tigrina } \\ \text { Scaphander lignarius } & \text { Nudibranchia Doridina } \\ \text { Scaphander punctostriatus } & \text { Doriopsilla areolata } \\ \text { Philine aperta } & \text { Doriopsilla pusilla } \\ \text { Philine quatripartita } & \text { Dendrodoris limbata } \\ \text { Aglaja tricolorata } & \text { Doriopsilla pelsenneri } \\ \text { Cylichna cylindracea } & \text { Phyllidia } \text { sp. } \\ \text { Anaspidea } & \text { Kaloploclamus ramosus } \\ \text { Aplysia depilans } & \text { Baptodoris cinnabarina } \\ \text { Notarchus punctatus } & \text { Doris verrucosa } \\ \text { Umbraculacea } & \text { Doris pseudoargus } \\ \text { Umbraculum mediterraneum } & \text { Doris sticta } \\ \text { Notaspidea } & \text { Doris sp. } \\ \text { Pleurobranchaea meckeli } & \text { Thordisa filix } \\ \text { Pleurobranchus membranaceus } & \text { Jorunna cf. tomentosa } \\ \text { Pleurobranchus testudinarius } & \text { Okenia elegans } \\ \text { Berthella ocellata } & \text { Geitodoris cf. planata } \\ \text { Berthella aurantiaca } & \text { Dorid sp. } \\ \text { Nudibranchia Dendronotina } & \text { Hypselodoris fontandraui } \\ \text { Tethys fimbria } & \text { Hypselodoris picta } \\ \text { Marionia blainvillea } & \text { Hypselodoris villafranca } \\ \text { Lomanotus marmoratus } & \text { Chromodoris purpurea } \\ \text { Tritonia plebeia } & \text { Discodoris stellifera } \\ \text { Tritonia hombergi } & \text { Peltodoris atromaculata } \\ \text { Tritonia sp. } & \text { Nudibranchia Aeolidina } \\ & \text { Facelina drummondi } \\ & \\ & \end{array}$

tigrina, Baptodoris cinnabarina, Thordisa filix and Kaloplocamus ramosus.

A dendrogram with the species richness from the different trawling grounds was produced (Figure 4), showing the similarities between trawling grounds with similar types of bottom. In particular, the opisthobranch fauna of Els Capets and La Fluviana, each one on one side of the Blanes Canyon and with similar depths and type of bottom (mud), resemble that found at La Planassa. The other two trawling grounds, Les Quaranta and Malgrat, with shallower depths, located near the coast and directly affected by the sediments carried by the River Tordera, remained as a clearly separated group.

\section{DISGUSSION}

The trawling grounds off Blanes, even if they have been submitted to a high fishing and trawling pressure during decades, are rich in several groups of invertebrates (Rubió, 1971; Gili et al., 1987a,b; Gili \& Pagés, 1987; Turon, 1988; this study). Our data show that they are also rich in opisthobranch molluscs, which seem to survive by exploiting the different substrata and feeding resources. The opisthobranch fauna in the studied area is constituted now by a total of 48 species (Table 4), of which 8 are Cephalaspidea s.s., 2 Anaspidea, 1 Umbraculacea, 5 Pleurobranchacea, and 33 Nudibranchia (6 Dendronotina, 3 Arminina, 1 Aeolidina and 22 Doridina). From these species, only 14 were registered also in the previous records (Ros, 1975) while 15 species were not previously 
mentioned (Table 2). The specimens of Gastropteron rubrum and Tethys fimbria represents the $55.59 \%$ of the total opisthobranchs collected in our two-year study and appeared in more than $40 \%$ of the samples; they are species with a high capacity of swimming. Four more species (Marionia blainvillea, Pleurobranchus membranaceus, Pleurobranchaea meckeli, Scaphander lignarius) were collected in more than $25 \%$ of the samples. Of the other species, 16 were collected in less than $5 \%$ of the samples. The reason for the scarce knowledge of the opisthobranchs of these subtidal areas is probably related to a combined effect of these low frequencies, the difficulty of using trawling methods and the high effort needed to know accurately the opisthobranch fauna inhabiting these kind of bottoms.

The trawling grounds with highest abundances and species richness in opisthobranchs were La Planassa and Els Capets. These are the two sites most visited by the fishermen due to the quality and relative abundance of cephalopods and commercially interesting fish (see above). However, if the data are analysed considering the number of samples taken on each site, these are not the richest opisthobranch sites for abundance/sample or species/ sample (Figure 3). This fact could obviously be related to the impact of the already mentioned high pressure of fishing on those sites. Terra Malgrat, due to its shallow depth $(50-60 \mathrm{~m})$, is not open for fisheries in summer time, and this may allow the communities to recover from the trawling pressures, thus being reflected in their opisthobranch fauna too. La Fluviana is quite far from shore (9-17 n.m.), and therefore is the less visited site; this lower trawling and fishing pressure would be reflected in a higher abundance and species richness in opisthobranchs/ sample.

The data show that sandy and detritic sites, such as La Planassa and Les Quaranta, possess more equilibrated percentages of the different opisthobranch groups (Figure 2). This could be due to the higher diversity of the invertebrate communities in these areas, with the presence of sponges, pennatulaceans and tunicates (see above), among others, with whom the opisthobranchs would have trophic relationships. Muddy sites, such as Els Capets and La Fluviana, present higher percentages of cephalaspideans, which may find there the ideal substratum for burrowing in search of their food, and of dendronotaceans, probably related to a higher abundance of filter-feeders such as anthozoans which they prey upon (Figure 2). It is also worth mentioning that in Terra Malgrat there is a relatively high abundance of dendronotaceans and arminaceans which could be related to the presence of alcyonarians and pennatulaceans (see above) which they prey upon. The abundance of filter-feeding communities here may be related to the fact that there are three submarine seawage outfalls in the area. All these facts correlate with the obtained dendrogram (PRIMER) indicating that similarities in the opisthobranch fauna are related to the type of bottom but also to the previously mentioned aspects (Figure 4).

The specimens collected during the two-year study, similarly to that reported by Ros (1975), are usually of large or medium sizes for the benthic species (e.g. Tethys fimbria, Scaphander lignarius) or they may be small but very abundant for the swimming species (e.g. Gastropteron rubrum). Usually they are species with wide distributions in the sea bottoms of the Atlantic and Mediterranean regions. This is the case for species such as Scaphander lignarius, Gastropteron rubrum, Philine aperta, Pleurobranchaea meckeli, Pleurobranchus membranaceus, P. testudinarius, Umbraculum umbraculum, Armina maculata, Marionia blainvillea, Tethys fimbria, Doris pseudoargus and Dendrodoris limbata. Surprisingly, the dendronotacean Marionia blainvillea has been recorded as extraordinarily abundant in this study, with 430 specimens, 140 from La Fluviana, 68 from La Planassa and 39 in Els Capets, while previously it was only collected in very few places along the Iberian Peninsula (Cervera et al., 1988). Interestingly, a seasonal pattern was observed for the cephalaspidean Scaphander lignarius, which showed three different sizeclasses, being the smallest one present only in summer time. More studies are needed to further study this seasonality.

Several species found during the study are noteworthy because of their taxonomic interest or their rarity. This is the case for Baptodoris cinnabarina, Thordisa filix, Lomanotus marmoratus and Okenia elegans. Baptodoris cinnabarina has been recently redescribed and cited for the first time in the Iberian Peninsula (Ballesteros \& Valdés, 1999), and seems to be relatively frequent in the circalittoral areas rich in sponges and other invertebrates of the Iberian Peninsula and the Balearic Islands (unpublished data from the authors). Thordisa filix, is also rare in the Iberian Peninsula but seems to be frequent in the areas off Blanes (Ballesteros, 1986; Ballesteros et al., 1999; this study). Lomanotus marmoratus was only cited for the Galician coasts in the north of the Iberian Peninsula (Urgorri \& Besteiro, 1983). Also, the finding of O. elegans is, as far as we know, the first record for the Iberian Peninsula. Several species collected are considered scarce and very little information is available about their biology and ecology. These include Kaloplocamus ramosus, Aglaja tricolorata, Doris sticta and the species of the genus Armina (A. maculata, A. tigrina and A. neapolitana). After this study, the total number of opisthobranch species reported for the trawling grounds off Blanes is now 48.

Thanks are due to H. Magalon (Institut National Agronomique de Paris-Grignon (INAPG), Paris, France; visitor at the CEAB-CSIC with Dr R. Sardà with a grant from the INAPG) and X. Perea for helping in the collection and processing of material from the trawls, and to Dr R. Sardà for advice. This work would not have been possible without the kind collaboration of the 'Confraria de Pescadors del Port de Blanes' and the crew members of the fishing boats: 'Na Teresa', 'Dolores', 'Milagros I', 'San Bartolomé', 'La Palomera', 'Joaquima', 'Núria', 'Rosa Mari', 'San Francisco' and 'Pili', which actively helped in the sorting of material from the samples and in the situation of the trawling grounds on the maps. A. Domènech had a fellowship FI from the Catalan Government. This study is part of the project Fauna Ibérica V (subproject Mollusca, Opisthobranchia DGSIC PB98-0532) of the Science Ministry of Spain.

\section{REFERENCES}

Ballesteros, M., 1981. Sobre un raro armináceo (Mollusca: Opisthobranchia) de la costa mediterránea española: Armina maculata Rafinesque, 1814. Publicaciones del Departamento de Zoología de la Universidad de Barcelona, 6, 27-31. 
Ballesteros, M., 1983. Primera cita de Armina tigrina (Mollusca: Opisthobranchia) para las costas españolas. Publicaciones del Departamento de Zoología de la Universidad de Barcelona, 9, 53-62.

Ballesteros, M., 1986. Nuevos datos sobre los Opistobranquios (Mollusca: Gastropoda) de los caladeros de arrastre de las costas catalanas. In Abstracts VI Congreso Nacional de Malacología, Puerto de la Cruz (Tenerife), September 1986, 10 pp.

Ballesteros, M., Avila, C. \& Domènech, A., 1999. The genus Thordisa Bergh, 1877 from commercial trawling areas off Blanes (Costa Brava, north-east Spain). In Proceedings of the 2nd International Workshop of Malacology, Menfi (Sicily, Italy), July 1999. Systematics, Phylogeny and Biology of Opisthobranch Molluscs.

Ballesteros, M. \& Valdés, A., 1999. Redescripción de Baptodoris cinnabarina Bergh, 1884 (Opisthobranchia, Doridina, Platydorididae) y discusión taxonómica de otras especies del género Baptodoris Bergh, 1884. Iberus, 17, 27-35.

Cervera, J.L., Calado, G., Gavaia, C., Malaquias, M.A.E., Templado, J., Ballesteros, M., García-Gómez, J.C. \& Megina, C., 2004. An annotated and updated checklist of the opisthobranchs (Mollusca: Gastropoda) from Spain and Portugal (including islands and archipelagos. Boletín Instituto Español de Oceanografía, 20(1-4), 1-95.

Cervera, J.L., Templado, J., García-Gómez, J.C., Ballesteros, M., Ortea, J.A., García, F.J., Ros, J. \& Luque, A.A., 1988. Catálogo actualizado y comentado de los opistobranquios (Mollusca, Gastropoda) de la Península Ibérica, Baleares y Canarias, con algunas referencias a Ceuta y la Isla de Alborán. Iberus, Supplement 1, 1-83.

Gili, J.M. \& Pagès, F., 1987. Pennatuláceos (Cnidaria, Anthozoa) recolectados en la plataforma continental catalana (Mediterráneo Occidental). Miscellània Zoològica, 11, 25-39.
Gili, J.M., Pagès, F. \& Barangé, M., 1987a. Zoantarios (Cnidaria, Anthozoa) de la costa y de la plataforma continental catalanas (Mediterráneo Occidental). Miscellània Zoologica, 11, 13-24.

Gili, J.M., Ros, J.D. \& Pagès, F., 1987b. Types of bottoms and benthic cnidaria from the trawling grounds (subtidal and bathyal) off Catalonia (NE Spain). Vie et Milieu, 37, 85-98.

Ortea, J., Valdés, A. \& García-Gómez, J.C., 1996. Revisión de las especies atlánticas de la fammilia Chromodorididae (Mollusca: Nudibranchia) del grupo cromático azul. Avicennia, Supplement 1, 1-165.

Ros, J., 1975. Opistobranquios (Gastropoda: Euthyneura) del litoral ibérico. Investigación Pesquera, 39, 269-372.

Rubió, M., 1971. Contribución al estudio de la fauna bentónica del litoral de Blanes. PhD thesis, University of Barcelona, Spain.

Templado, J., Guerra, A., Bedoya, J., Moreno, D., Remón, J.M., Maldonado, M. \& Ramos, M.A., 1993. Fauna marina circalitoral del sur de la Península Ibérica. Resultados de la Campaña Oceanográfica "Fauna I". Museo Nacional de Ciencias Naturales, CSIC. 137 pp.

Turon, X., 1988. Ascidias de los caladeros de arrastre de la costa catalana (Mediterráneo noroccidental). Investigación Pesquera, 52, 467-481.

Urgorri, V. \& Besteiro, C., 1983. Inventario de los moluscos opistobranquios de Galicia. Investigación Pesquera, 47, 3-28.

Submitted 4 April 2005. Accepted 13 February 2006. 